\title{
THE ORGANIZATION AND PROCEDURE OF THE NATIONAL WAR LABOR BOARD
}

\author{
E. Riggs McConneli*
}

During the last year the National War Labor Board has developed a set of procedures for handling labor disputes which is to some degree unique. The jurisdiction of the Board has been considerably extended by the President's Executive Order of October 3,1942 , and no doubt the procedures will be changed to some extent to meet the new administrative load. ${ }^{1}$ However, it seems certain that the present system stands so close to the core of the theory on which the Board operates that whatever changes are made will have the system as a point of departure and for that reason it seems appropriate to outline the present procedures.

\section{Legal Basis of the Board}

The National War Labor Board was created by Executive Order No. gor7 issued by the President on January 12, 1942. ${ }^{2}$ This Order provided that the Board would exist in the Office for Emergency Management which, of course, is an appendage of the White House. When the Order is winnowed down to its simplest terms it provides that the Board, within certain limitations and under rules promulgated by it, shall finally determine all labor disputes which might interrupt work that contributes to the effective prosecution of the war. From a procedural standpoint it is always important to bear in mind that the Board is an agency of the President, exercising the President's constitutional powers as Chief Executive and Commander-in-Chief of the Armed Forces. The courts have never had an occasion to review the Presidential powers specifically in this connection, and there is really no case law pertinent enough to warrant analysis. It seems clear, however, that the interruption of production by labor disputes falls so close to the kernel of the successful prosecution of the war that the Presidential powers are beyond dispute. In the last war, President Wilson created the old War Labor Board on the same theory, and his action consti-

"A.B., 1929, Davidson College; LL.B., I934, University of Virginia. Member of the New York and North Carolina Bars. Counsel to the Chairman, National War Labor Board.

${ }^{2}$ The recent Executive Order of October 3, 1942, 7 FED. REG. 7871, provides that there should be no increases or decreases in wage rates resulting from voluntary agreement, collective bargaining, conciliation, arbitration, or otherwise, unless notice of such increase or decrease is fled with the National War Labor Board and unless the National War Labor Board has approved such increase or decrease. In brief, this Order increases the jurisdiction of the War Labor Board to include voluntary wage increases or decreases. It still retains its jurisdiction over labor disputes generally.

27 FED. REG. 237 (1942). 
tutes the constitutional precedent on which the present Board is based. ${ }^{3}$ At the present time there are no statutes which expressly implement the Board in any way. ${ }^{4}$

In addition to the Presidential power the Board is likewise bottomed on an agreement, between representatives of the two national labor organizations and selected representatives of industry, reached at a conference called by the President on December 17, I941. Of course, no one seriously contends that this agreement was legally binding, in the strict sense of the word, upon all the various employers and workers in the country at large. However, it stands as a very firm moral basis for the Board's actions and is deemed extremely important because it signifies a basic adherence to democratic principles. The precedent for the agreement is likewise found in President Wilson's creation of the old War Labor Board. There was a conference and agreement then too.

From the nature of the Board's function as a determinator of disputes it operates with a great many of the indicia of a court. Its final decisions culminate in a Directive Order addressed to the parties to the dispute which in many respects has the character of a decree in equity. In addition to the Directive Order the Board likewise in many cases issues an opinion explaining its decision. Under the Executive Order, the Board's Directive Order, through clear delegation of authority, is in essence an order of the President under his powers as Chief Executive and Commander-in-Chief. In this respect the Board's position is quite different from that of the National Defense Mediation Board which preceded it. That board was given power merely to make recommendations to the parties which would be published at large so that the public might form an opinion of the merits of the dispute, to the end that it might be resolved at the bar of public opinion.

\section{Jurisdiction of the Board}

In Section 3 of the Executive Order, by clear implication the Board is given general jurisdiction over all labor disputes which might interrupt work that contributes to the effective prosecution of the war. This general jurisdiction is circumscribed in the Order itself in three different respects.

(r) Section 2 provides that the Order does not apply to labor disputes for which there are existing procedures for adjustment until those procedures have been exhausted. The National Mediation Board which is set up by statute to settle railway disputes exemplifies the type of agency contemplated by this limitation in the Order.

(2) Another limitation is found in Section 3 where it is provided that the procedure for settling disputes shall first embrace direct negotiations between the parties or resort to agreed collective bargaining procedure and that secondly the Commissioners of the Conciliation Service in the Department of Labor should be called

\footnotetext{
${ }^{3}$ Proclamation of President Wilson creating the National War Labor Board, April 8, 1918, quoted in Rice, The Law of the National War Labor Board, supra at p. $47 \mathrm{I}$.

"The Act of October 2, 1942, entitled An Act to Amend the Energency Price Control of 1942 to Aid in Preventing Inflation and for other purposes, provides that any person who wilfully violates any regulation promulgated by the President under the Act relating to wages shall be fined not more than $\$ 1000$. This section would seem to implement by penal action at least certain orders of the Board.
} 
in to conciliate the dispute. If these two methods fail the Order provides that the Secretary of Labor shall certify the dispute to the Board which shall finally determine it. There is a proviso in the section, however, which operates to make the outlined procedure more precatory than jurisdictional. This proviso gives the Board power to assume jurisdiction on its own motion. As a practical matter the Board has found it necessary to exercise this power in a situation in which it would be a fruitless matter to require the earlier steps outlined in the Order. ${ }^{5}$

(3) Section 7 of the Order provides that nothing in it shall be construed as superseding or in conflict with the Railway Labor Act which set up the Railroad Mediation Board, the National Labor Relations Act, or the Fair Labor Standards Act and certain other acts which are relatively unimportant. Section 7 , in the strict sense, limits the substantive power of the Board. That is to say, it cannot order action which would contravene the statutes.

The touchstone to the jurisdictional question as far as parties or types of businesses are concerned lies in the fact that in the ultimate analysis the Board, within the very broad limits outlined above, determines its own jurisdiction. In doing so, it has approached the problem very pragmatically. In essence the criterion has been twofold. Does the dispute in question really substantially affect the war effort ${ }^{6}$ and secondly, is it necessary for the Board to use its offices to avert an interruption of production? In applying this pragmatic test the Board has assumed jurisdiction not only of disputes involving basic war industries but also of disputes involving hotels, ${ }^{7}$ a laundry which was servicing an Army camp, ${ }^{8}$ a dispute between fishermen and the owners of the fleet, ${ }^{9}$ a large commercial mail order house, ${ }^{10}$ processors of peanuts, ${ }^{11}$ a city streetcar system, ${ }^{12}$ and a variety of other types of business which would appear at first sight to be rather remotely connected with the war effort.

When the records in the cases are examined, however, it is clear that it should not

"In the Matter of General Motors Corporation the Board assumed jurisdiction prior to certification of a dispute involving overtime provisions of the existing contract between the Corporation and the International Union of the United Automobile, Aircraft and Agricultural Implement Workers of America. The Board, thercupon, on February 27 , 1942 refused to pass upon the issue inasmuch as the adjustment machinery provided for in the contract had not been utilized.

On September 15, 1942, the Board, without certification, requested certain companies alleged by the United Steelworkers of America to be a part of the basic steel industry to show cause why the Board's decision in the case of the subsidiaries of the United Steel Corporation should not apply to their company. This assumption of jurisdiction was a departure from established methods of procedure but was considered a practical method for disposing of a large number of possible cases involving identical issues.

- The opinion in the Matter of Montgomery Ward and Company, Case No. 192, contains the completest treatment of the general jurisdictional question. In that case, Dean Morse, public member, stated: "the decisions of the Board show its position that the question as to what disputes do or do not "interrupt work which contributes to the effective prosecution of the war' is not one which can be determined by the application of some hard and fast rule. The cases differ one from another in many respects, and, hence, the problem becomes one of balancing interests and passing judgment upon degrees of effects which the various disputes have upon the war effort."

${ }^{7}$ San Francisco Hotel Employees Association, Case No. 2r.

${ }^{8}$ New Orleans Laundrymen's Club, Case No. 91.

${ }^{\circ}$ Federated Fishing Boards of New England and New York, Case No. I6.

${ }^{10}$ Montgomery Ward and Company, supra note 6 .

11 Four Peanut Companies at Suffolk, Case No. 500.

${ }^{12}$ Los Angeles Railway Corporation, Case No. $x$. 
be implied that the Board will assume jurisdiction of any dispute. One important criterion, but not a controlling one, is whether or not the particular company involved is under contract with the Government to deliver supplies. Another important factor lies in whether or not the particular dispute might spread and disaffect other workers in the community. In short, the question is always a factual one. It could be said, finally, that the Board has been liberal in its construction of its jurisdiction over parties.

With respect to subject matter, the Board has jurisdiction over all the various issues that might be classified as falling within the broad definition of a labor dispute. At the Industry-Labor Conference in December, r94I, the industry and labor representatives were at daggers' points as to whether or not the contemplated Board should have jurisdiction over the union security issue. And in the case involving the Inland Steel Corporation, ${ }^{13}$ the company took the position that the Board did not have the authority to dispose of the union security question in that case. By unanimous decision the Board ruled that it did have such jurisdiction, and since that time there has been little argument with respect to the scope of the Board's power to dispose of types of issues.

With regard to the Board's position in relation to other agencies handling labor disputes, of course the National Labor Relations Board furnishes the cardinal example. The NLRB and the Board have established a liaison which has obviated any real conflict in the functions of the two Boards. The WLB in a number of cases has adopted a rule that it is bound by the decisions of the NLRB in its particular field even though those decisions are in the process of litigation. ${ }^{14}$ In one case it ordered an employer to negotiate with a union certified by the NLRB even though the employer was prepared to contest the election by court proceedings. ${ }^{15}$ The touchstone to the relationship between the two Boards lies, as stated above, in liaison. The WLB supplements the NLRB by its more flexible and more rapid procedure whenever it is determined that use of WLB procedure is desirable to avoid interruption of production. In one case the Board had before it a dispute which had gone through the National Mediation Board, but the owner of the railroad had refused to follow the recommendation of that board. In this situation there was little doubt that the procedures of the Mediation Board had been exhausted, and the Board ordered arbitration of the dispute under its direction.

In several cases the Board has expressed a reluctance to settle any dispute between a municipal governmental agency and its employees. ${ }^{16}$ The expressed theory of the Board is that a governmental agency has within itself the authority to settle its own employment conditions and that the Federal Government should not enter upon such an area.

\footnotetext{
${ }^{13}$ Inland Steel Company, Case No. 35.

14 Lcbanon Steel Foundry, Case No. 333. In this case, a petition for a writ of certiorari is pending in the Supreme Court. $\quad{ }^{15}$ Ohio Public Service Company, Case No. 169.

${ }_{10}$ Municipal Government City of Newark and State, County and Municipal Worlecrs of America, CIO, WLB Release, March 5, x942; Lower Colorado River Authority, Case No. 290; Turlock Irrigation District, Case No. 273.
} 
From the decisions of the Board it is clear that, aside from sheerly jurisdictional matters, the Board concedes there is a very definite limit to its authority growing out of existing law and particularly the federal system. Thus, in an early case the Board refused to consider a question which had been previously adjudicated by a court of competent jurisdiction in California. ${ }^{17}$ By negative implication it has indicated a policy of not ordering any action which would be a breach of an existing contract except under very exceptional circumstances ${ }^{18}$ and it has likewise been careful that the actions ordered do not violate any existing state or federal statutes. ${ }^{19}$

As yet the Board has not taken any cases involving agricultural workers, and at present it is a matter of doubt whether or not the Board on grounds of policy would exclude agricultural disputes although the Executive Order seems broad enough to include them.

\section{Organization of the Board}

From an operational point of view the Board functions in four different groups: (1) The Board itself; (2) associate members and ad hoc mediators; (3) staff mediators and investigators; (4) incidental referees and arbitrators.

The Board itself is composed of 12 members; four representing the public, four labor, and four industry. The industry and labor members each have an alternate. All the members are Presidential appointees. The public members reside in Washington where the Board has offices in the Department of Labor. The Board holds regular meetings on Tuesday of each week, the meetings running through to the end of the week. Six members constitute a quorum of the Board provided that there is equal representation between employers and labor. A majority vote at any meeting determines a decision of the Board. The meetings are either in executive session, closed to the public, or in hearing sessions when the parties in exceptional cases present arguments to the Board. The hearing sessions are open to the public. The Board has a standing committee on new cases and a standing committee on procedure.

There are some 20 associate members who likewise are presidential appointees. Strictly speaking, the associate members are not members of the Board in that they are not entitled to participate and vote at Board meetings. In addition to the associate members, there are a number of ad hoc mediators who serve the Board with great regularity and stand in the same stratum as the associate members. Together these two groups either mediate particular disputes assigned to them or make findings of fact with respect to a particular dispute. There is equal representation among the associate members and the ad hoc mediators from the public, industry and labor. As a usual rule, they operate in panels of three with tripartite representation. In addi-

\footnotetext{
${ }^{27}$ Los Angeles Railway Corporation, Case No. $\mathrm{x}$.

${ }^{18}$ In the Matter of U. S. Steel Corporation, Feb. 27, 1942, the company had pressed a strong argument that a retroactive wage order would violate a contractual right. In its opinion the Board was very careful to point out that there would be no violation of the contract in that particular case and by negative implication it expressed a policy of not interfering with existing contract rights except under very exceptional circumstances.

${ }^{10}$ Federal Shipbuilding and Drydock, April 24, 1942, date of issue.
} 
tion to the associate members and ad hoc mediators, the Board has a staff of mediation officers and investigators who are assigned to investigate or mediate particular disputes. The staff members usually operate alone. The Board likewise has a permanent list of men throughout the country who can serve locally as referees in any dispute and from time to time the Board directs the parties to submit a dispute to a local referee or arbitrator whose decision is subject to review by the Board.

The Board has an Executive Secretary who is charged with the responsibility of administering the affairs of the Board, and likewise an Administrative Associate Member who is primarily charged with the responsibility of administering the mediaton of cases prior to the time that they are finally put before the Board.

\section{Procedure of the Board}

-Every effort has been made to keep the Board's procedures as fluid as possible. In this respect, the procedural theory of the Board differs from the procedures of the old War Labor Board which were more or less formal. There the parties were required to file complaints and answers and take various steps comparable to the procedural steps in a lawsuit. The present Board is trying to avoid formality as much as possible. The normal case, however, usually goes through a more or less regular procedure. The first action is taken by a committee composed of the Executive Secretary and members of the Conciliation Service, known as the Certification Committee. This Committee determines what disputes should be certified to the Board. When it is decided that a dispute should be certified, a certification is sent over the signature of the Secretary of Labor, briefly setting forth the facts about the dispute. There is likewise a report from the Conciliator who is familiar with the case. As soon as the case is certified, it is referred to the New Case Committee or Sub-Committee of the New Case Committee, which determines how the case should be handled. At this stage, one of four things might be done:

x. If the case involves a simple issue or a question of jurisdiction or requires some interim Board action, it is immediately put on the Board calendar and will be taken up by the Board in order, unless special circumstances make it desirable that it be given a preference.

2. If the case involves multiple issues and is relatively important, it is placed on the mediation docket and a panel of associate members or ad hoc mediators is assigned to mediate the case. Dates are set for the hearings, the Executive Secretary notifies the parties, and thereafter the mediation takes place. This either culminates in agreement on all issues or in the filing of a report by the panel setting forth the panel's findings and recommendations for Board action.

3. If the facts surrounding the case are obscure, the New Case Committee sends a staff member to investigate and mediate the dispute to the end that the Board may determine what procedure is best adapted to the particular controversy.

4. If the case primarily involves an issue of wages, the New Case Committee can refer the dispute to a local referee who subsequently holds hearings and makes findings. The referee's decision is subject to review by the Board. 
When the dispute is placed on the mediation docket or is referred to the referee, the parties to the dispute are required to submit in advance a brief and concise statement setting forth their position. This statement is designed to limit the scope of the mediation or reference. The mediation proceeding itself is very informal. The public member presides and after allowing an opening statement by either side, conducts the proceeding along the lines which in the judgment of the panel are designed to bring the quickest results. In the event that the panel is not able to winnow down all the issues by agreement, it gathers together all the information which it deems pertinent and prepares a report for the Board. The report contains findings and recommendations. After the report is prepared, copies are sent to the parties and the case is put on the Board agenda. The Board thereafter considers the case and makes its decision in executive session. In exceptional cases, public hearings are held before the Board makes its decision.

Lawyers without a very definite background in labor law frequently feel like strangers in a strange land when they first come into contact with the Board procedure. Primarily this results from the fluid and informal method used by the panels Likewise the Board's lack of process or system of pleading seems strange to a lawyer

The Board does not adhere to the rules of evidence and there is no formal sub. mission of proof under oath or examination of witnesses. There are three reasons for this: (I) the tripartite representation on the Board and in the panels to a large degree gives both sides the normal protection which the rules of evidence are designed to afford; (2) the nature of the issues in labor disputes does not lend itself to strict judicial proof; (3) from the nature of the disputes, the Board has to gather information itself from various investigations, utilizing to a large degree the government fact-finding agencies. Usually, both sides are given the opportunity to submit all that they care to submit in the way of documentary proof or oral testimony, and, if any real issue of fact comes up, the panel or the Board conducts an independent investigation.

Where there is a divided panel recommendation to the Board, or in exceptional cases where the Board feels it appropriate to have a public hearing, the parties are notified of the hearing and thereafter appear before the Board to present arguments. Many of the parties on their own motion have submitted briefs, and in some instances the Board has requested briefs. The hearing sessions are open to the public. As a usual rule, each side is given 45 minutes to present arguments.

Since the Board is an appendage of the White House, the President as Chief Executive and Commander-in-Chief of the Armed Forces enforces the Board's orders. In three instances, the orders of the Board have been openly defied, and the President promptly ordered either the Army or the Navy to take control of the plants and operate them until the difficulties had been resolved. ${ }^{20}$

Whether an order of the Board could be enforced by a court of equity is a question which has never been decided. It is clear, however, that a strong argument could be made that the equity jurisdiction would attach.

${ }^{20}$ Matter of the Toledo, Peoria and Western Railway Company, Case No. 48; General Cable Company, Case No. 247; S. A. Woods Machine Co., Case No. I60. 